\title{
HIGHLIGHTS OF
}

\section{FOUNDATION YEARBOOK}

\section{Estimated foundation giving unchanged in 2010 with modest growth in 2011; expected to remain stable in 2012}

Giving by this country's more than 76,000 grantmaking foundations stabilized at $\$ 45.7$ billion in 2010 , nearly unchanged from 2009 . This followed a record 2.1 percent decline in giving between 2008 and 2009. Numerous factors contributed to the relative stabilization of giving following the unprecedented 17 percent drop in foundation assets in 2008 , including the beginning of a stock market resurgence in the latter half of 2009, the commitment of many foundations to maintaining their grants budgets or reducing the extent of reductions relative to their assets losses, and new resources provided by recently established or newly large foundations.

The Foundation Center estimates that foundation giving returned to modest growth in 2011. As the economic recovery remains shaky, the outlook for 2012 and beyond remains uncertain. Nonetheless, while it may take some time to return to the levels of giving recorded prior to the Great Recession it seems unlikely that foundations will institute further pronounced reductions in their giving.

\section{Effect of Inflation on Foundation Giving, 2000 to 2010}

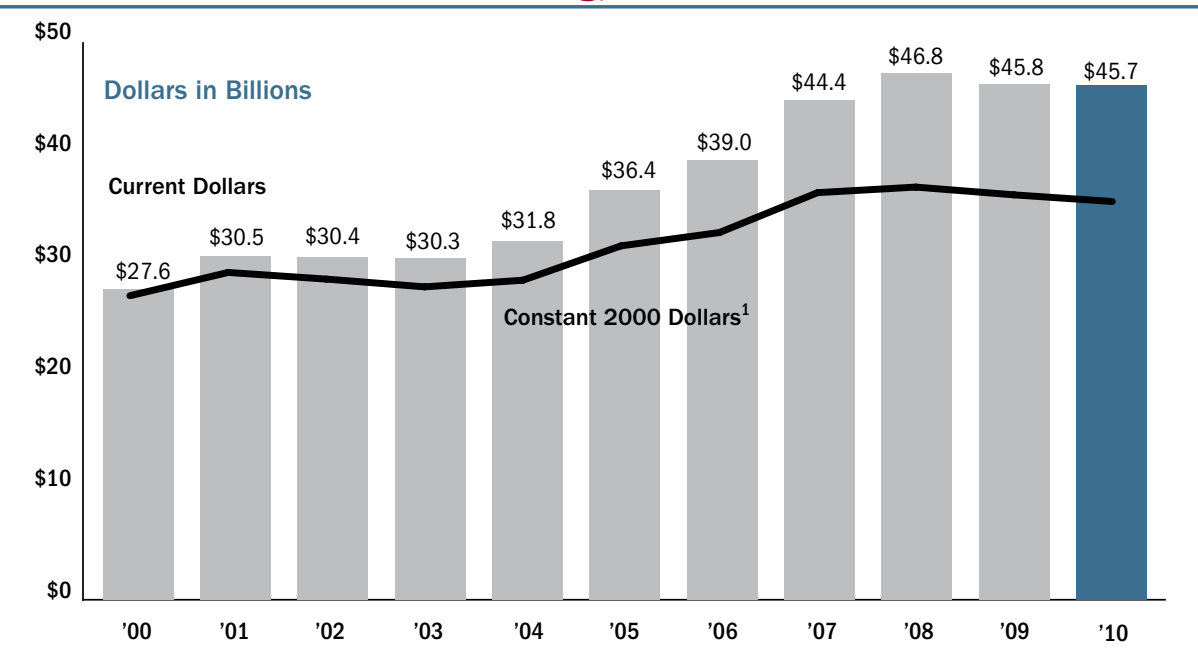

Source: The Foundation Center, Foundation Yearbook, 2011. Figures estimated for 2010.

${ }^{1}$ Constant 2000 dollars based on annual average Consumer Price Index, all urban consumers, as reported by the U.S. Department of Labor, Bureau of Labor Statistics, as of April 2011. 


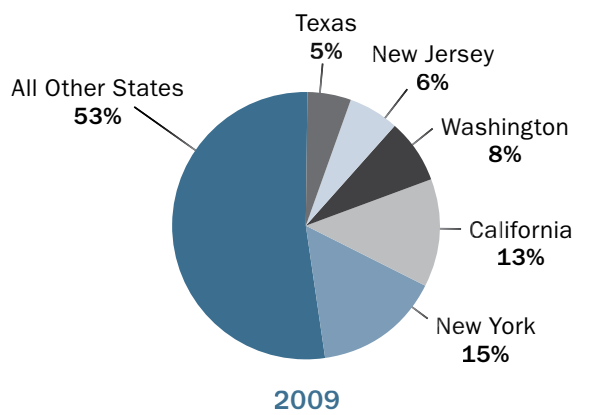

Total Giving $=\$ 45.8$ billion

Source: The Foundation Center, Foundation Yearbook, 2011. Due to rounding, figures may not add up to 100 percent.

Distribution of Foundation Assets by State, 2009

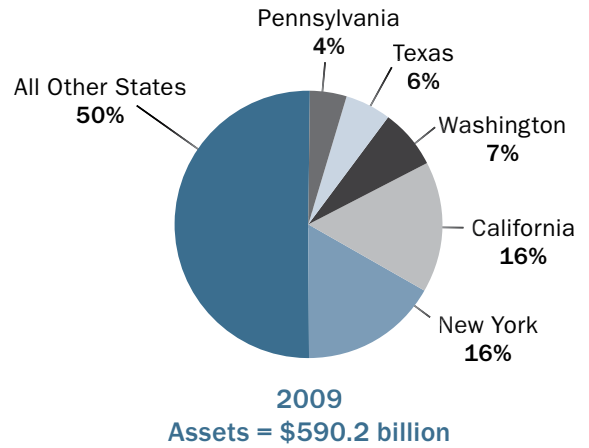

Source: The Foundation Center, Foundation Yearbook, 2011. Due to rounding, figures may not add up to 100 percent.

Inflation-adjusted Foundation Assets, 2000 to 2010

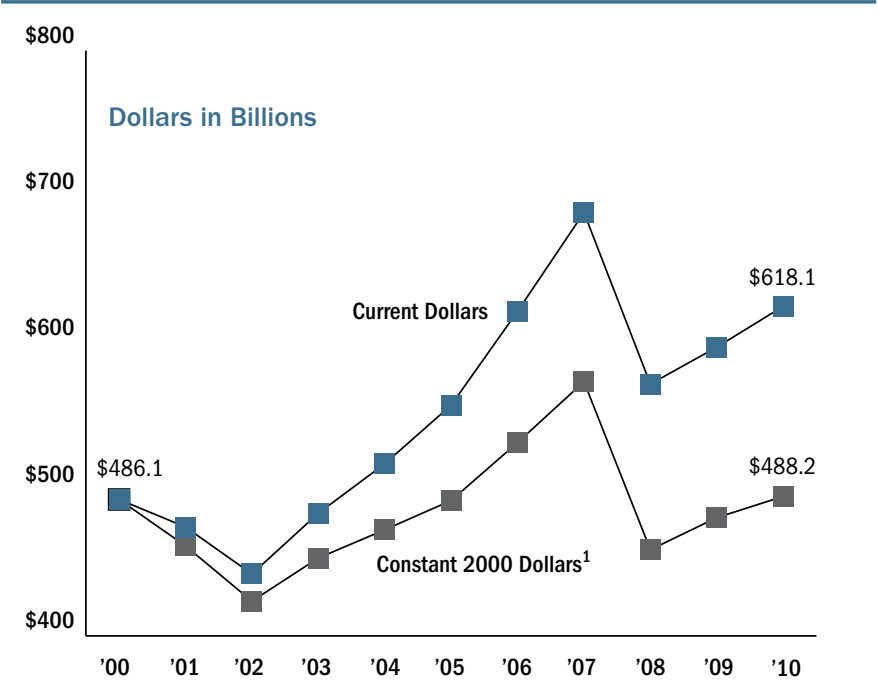

Source: The Foundation Center, Foundation Yearbook, 2011. Figures estimated for 2010. ${ }^{1}$ Constant 2000 dollars based on annual average Consumer Price Index, all urban consumers, as reported by the U.S. Department of Labor, Bureau of Labor Statistics, as of April 2011.
FOUNDATION GIVING IN 2010 AND 2011

- Giving decreased a marginal 0.2 percent to an estimated $\$ 45.7$ billion in 2010

- Adjusted for modest deflation, foundation giving in 2010 posted an estimated 1.8 percent real-dollar reduction

- Foundation giving in 2011 is expected to remain flat

- Assets rose by 4.7 percent to an estimated $\$ 618.1$ billion in 2010

\section{FOUNDATION GROWTH, GIVING, AND ASSETS THROUGH 2009}

- Number of grantmaking foundations exceeded 76,500

- Actual number of foundations increased by 950 compared to a peak gain of nearly 6,400 in 2000

- Giving by the nation's grantmaking foundations slipped 2.1 percent to $\$ 45.8$ billion

- Giving by the 25 largest funders jumped 14.2 percent to $\$ 10.8$ billion

- Assets of all active U.S. foundations rose 4.5 percent to $\$ 590.2$ billion-beginning a slow recovery from a record fall of 17.2 percent in 2008

- For the 25 largest foundations, assets increased just over 13 percent

- Gifts into foundations totaled $\$ 40.9$ billion, up 3.3 percent from the prior year

- Number of foundations receiving gifts and bequests of at least \$5 million decreased from 1,051 to 897

\section{About Foundation Yearbook}

Foundation Yearbook, 2011 Edition, documents changes in the actual number, giving, and assets of all U.S. private and community foundations through 2009 and provides estimates of foundation giving through 2010 . The report provides an overview of the state of foundation giving in the current year and beyond; comparisons of foundation activities by foundation size; and breakdowns of foundation resources by geographic location and grantmaker type. Foundation Yearbook is part of the Foundations Today Series of annual research reports on foundation growth and giving.

Findings presented in Foundation Yearbook are based on aggregate fiscal data collected by the Foundation Center on all active U.S. foundations. Estimates for 2010 are based on survey figures reported by 1,141 large and mid-size foundations combined with year-end fiscal indicators for all grantmaking foundations.

\section{ORDER TODAY!}

Foundation Yearbook, 2011 Edition, is available for $\$ 45$ or as part of the Foundations Today Series, our annual three-book set of research reports (\$95).

Online: foundationcenter.org/marketplace

Toll-Free: (800) 424-9836 (9 am-5 pm EST)

Call for bulk order discount information or to pay by check. 


\section{TRENDS BY REGION AND STATE IN 2009}

\section{Regions:}

- The Northeast experienced the fastest rate of growth in the number of foundations

- The West had the steepest decline in giving

- All four regions showed asset gains, with the Northeast registering the largest increase in assets

\section{States:}

- Thirty states plus the District of Columbia posted a decrease in foundation giving

- Arkansas showed the fastest rate of growth in giving as well as in actual grant dollar gains

- Delaware ranked first based on giving per capita due to its small population and the presence of one of the largest pharmaceutical operating foundations

- New York reported the largest amounts of foundation giving and assets overall, followed closely by California

- Rhode Island reported the fastest rate of growth in assets with a gain of 37.1 percent
Change in Foundation Number, Giving, and Assets by Region, 2008 to 2009
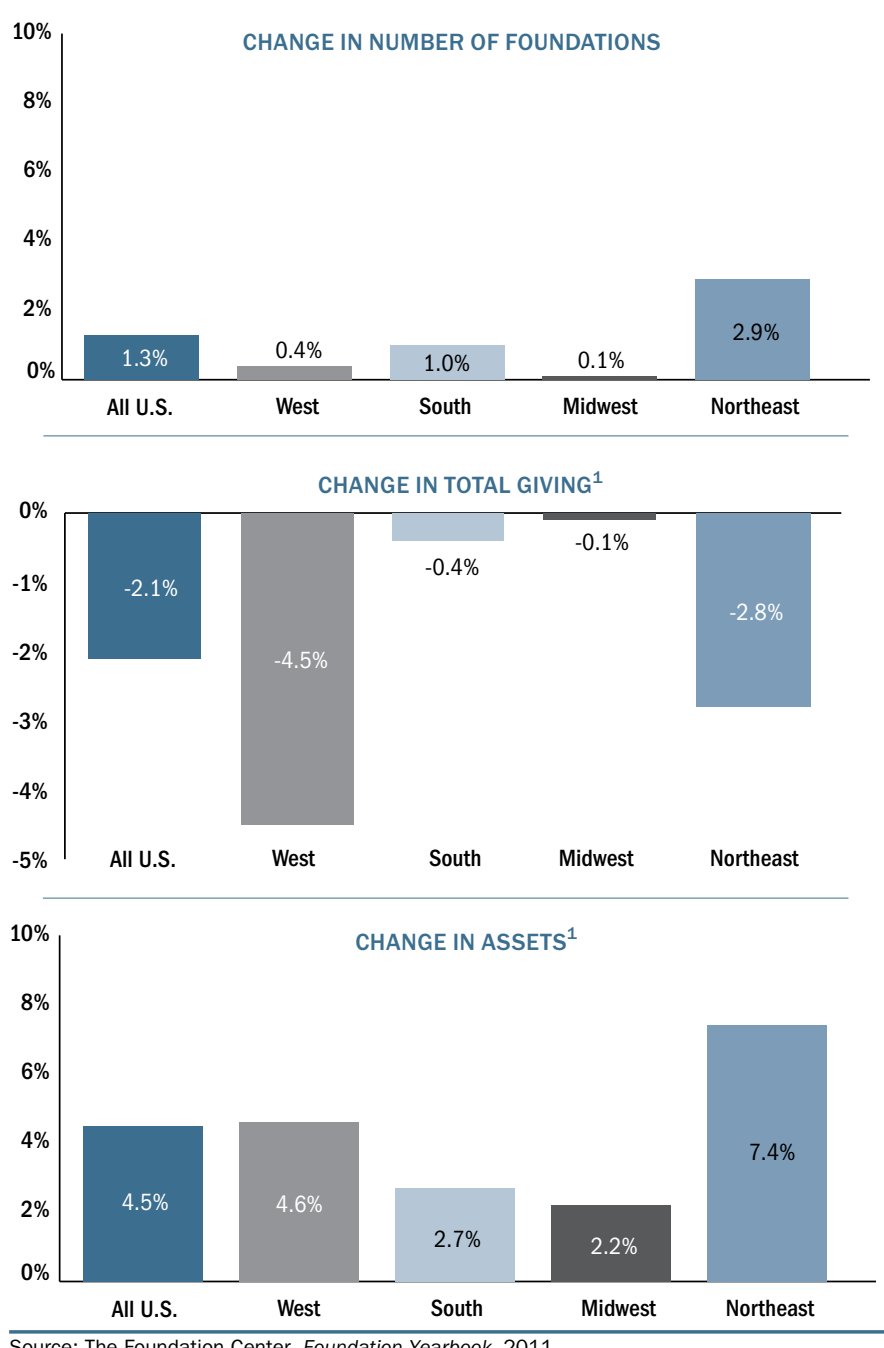

Source: The Foundation Center, Foundation Yearbook, 2011.

${ }^{1}$ Percent change based on currrent dollars.

\section{Grantmaking Foundations by State, 1975 and 2009}

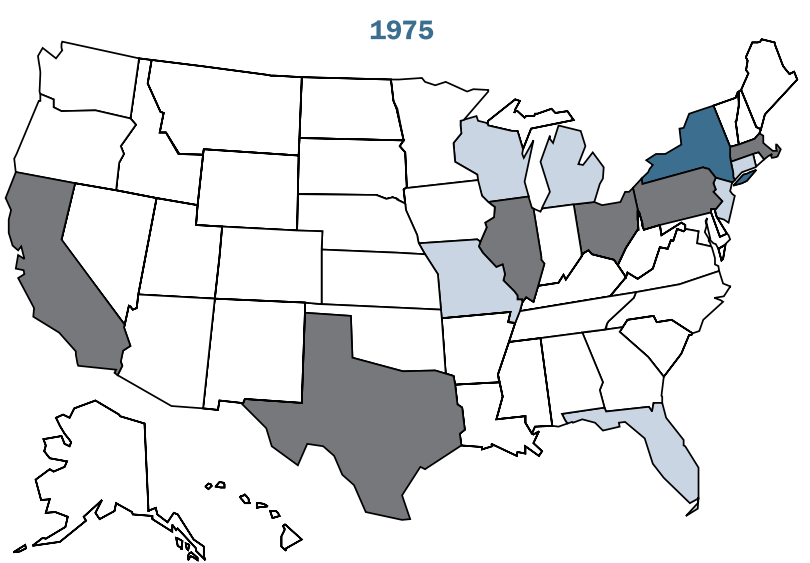

Total Foundations $=21,877$

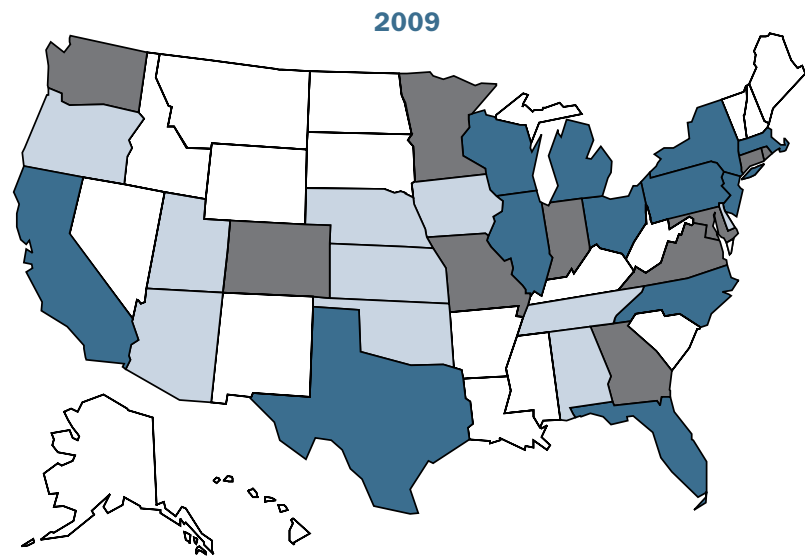

Total Foundations $^{1}=76,545$

500-under 1,000

Under 500 


\begin{tabular}{|c|c|c|c|}
\hline & 2008 & 2009 & $\begin{array}{c}\% \\
\text { Change }\end{array}$ \\
\hline \multicolumn{4}{|l|}{ All Foundations } \\
\hline No. of Foundations & 75,595 & 76,545 & 1.3 \\
\hline Total Giving & $\$ 46,781$ & $\$ 45,778$ & -2.1 \\
\hline Total Assets & $\$ 564,951$ & $\$ 590,188$ & 4.5 \\
\hline Gifts Received & $\$ 39,554$ & $\$ 40,862$ & 3.3 \\
\hline \multicolumn{4}{|l|}{ Independent } \\
\hline No. of Foundations & 67,379 & 68,508 & 1.7 \\
\hline Total Giving & $\$ 33,819$ & $\$ 32,753$ & -3.2 \\
\hline Total Assets & $\$ 456,025$ & $\$ 482,954$ & 5.9 \\
\hline Gifts Received & $\$ 24,068$ & $\$ 27,054$ & 12.4 \\
\hline \multicolumn{4}{|l|}{ Corporate } \\
\hline No. of Foundations & 2,745 & 2,733 & -0.4 \\
\hline Total Giving & $\$ 4,570$ & $\$ 4,691$ & 2.6 \\
\hline Total Assets & $\$ 20,335$ & $\$ 19,299$ & -5.1 \\
\hline Gifts Received & $\$ 4,615$ & $\$ 3,966$ & -14.1 \\
\hline \multicolumn{4}{|l|}{ Community } \\
\hline No. of Foundations & 709 & 737 & 3.9 \\
\hline Total Giving & $\$ 4,492$ & $\$ 4,174$ & -7.1 \\
\hline Total Assets & $\$ 49,623$ & $\$ 49,491$ & -0.3 \\
\hline Gifts Received & $\$ 5,620$ & $\$ 4,814$ & -14.3 \\
\hline \multicolumn{4}{|l|}{ Operating } \\
\hline No. of Foundations & 4,762 & 4,567 & -4.1 \\
\hline Total Giving & $\$ 3,900$ & $\$ 4,161$ & 6.7 \\
\hline Total Assets & $\$ 38,968$ & $\$ 38,444$ & -1.3 \\
\hline Gifts Received & $\$ 5,250$ & $\$ 5,027$ & -4.3 \\
\hline
\end{tabular}

Source: The Foundation Center, Foundation Yearbook, 2011. Dollars in millions. Percent change represents current dollars. Includes only foundations that awarded grants in the latest fiscal year.

\section{GIVING AND GROWTH OF INDEPENDENT,} CORPORATE, AND COMMUNITY FOUNDATIONS IN 2009

- Giving by independent foundations dropped 3.2 percent in 2009

- Independent foundation assets rose 5.9 percent in the latest year, following a 19.2 percent plunge in 2008

- Corporate foundation giving rose 2.6 percent in 2009

- Corporate foundation assets dropped 5.1 percent in 2009, after a 7.2 percent decrease in 2008

- Giving by community foundations dropped 7.1 percent in 2009

- Community foundation assets slipped 0.3 percent in 2009, following a 12.5 percent fall in 2008
For more information on this report, published in December 2011, contact Marc Almanzor, at (212) 807-2467 or mga@foundationcenter.org.

"Highlights of Foundation Yearbook" can be downloaded at foundationcenter.org.

Number of Foundations, Giving, Assets, and Gifts Received by Foundation Type, 2009

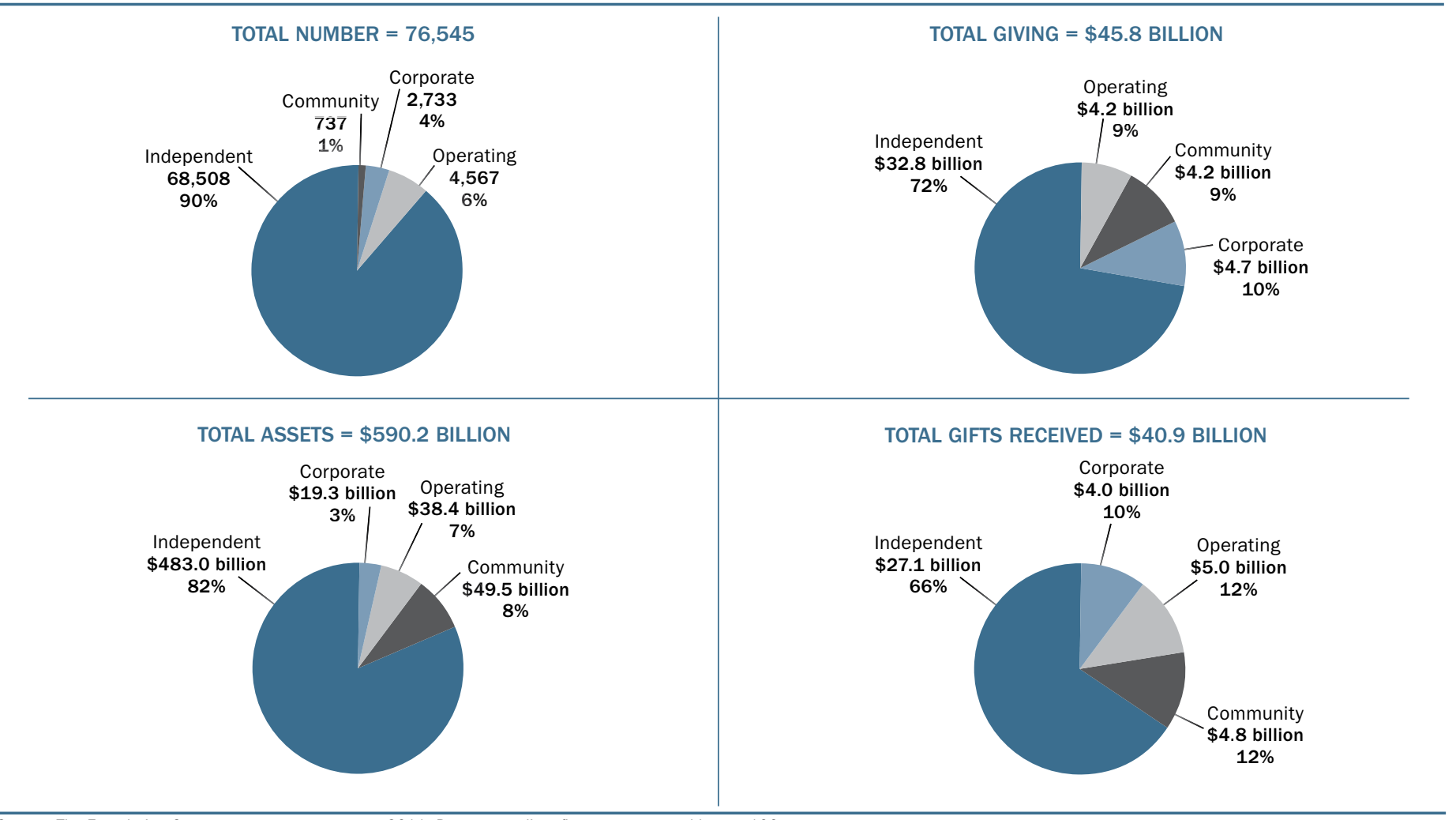

